\title{
Konsep Pendidikan Karakter Berbasis Ilmu Hikmah pada Institut Parahikma Indonesia (IPI) Gowa
}

\author{
Abd. Syukur Abu Bakar \\ Dosen UIN Alauddin Makassar dpk UIM \\ syukur.abubakar@yahoo.com
}

\begin{abstract}
This article elaborates on the implementation of character-based science education at the Institute of Parahikma Indonesia (IPI) Gowa. The results of this qualitative research indicate that the implementation of character education based on the science of wisdom at the Institute of Parahikma Indonesia (IPI) Gowa is always associated with the five pillars of development, which initially has been preceded by the strengthening of students' understanding of the nature of creation itself on earth. Problems encounter includes three aspects, in this case, the science of wisdom that has not been socialised widely, the understanding of lecturers who have not maximized, and the limitations of students in understanding the effects of several factors. The solution then is to intensify the integration of the science of wisdom on the five pillars of development in a civilized, intelligent, and thriving shrine.
\end{abstract}

\begin{abstract}
Abstrak
Artikel ini mengelaborasi implementasi pendidikan karakter berbasis ilmu hikmah pada Institut Parahikma Indonesia (IPI) Gowa. Hasil penelitian kualitatif ini menunjukkan bahwa implementasi pendidikan karakter berbasis ilmu hikmah pada Institut Parahikma Indonesia (IPI) Gowa selalu dikaitkan dengan lima pilar pengembangan yang pada awalnya telah didahului dengan penguatan pemahaman mahasiswa tentang hakikat penciptaan dirinya di muka bumi.Kendala yang dihadapi mencakup tiga aspek yang dalam hal ini ilmu hikmah yang belum memasyarakat, pemahaman dosen yang belum maksimal, serta keterbatasan mahasiswa dalam memahami akibat beberapa faktor. Solusinya kemudian adalah mengintensifkan integrasi ilmu hikmah pada lima pilar pengembangan dalam semboyang berperadaban, cerdas, dan termpil.
\end{abstract}

Keywords: Pendidikan Karakter, Ilmu Hikmah, Esoterisme Agama 


\section{A. Pendahuluan}

Institut Parahikma Indonesia (IPI) Gowa merupakan salah satu perguruan tinggi agama Islam swasta yang berdiri berdasarka izin operasional Menteri Agama Republik Indonesia Nomor 2732 Tahun 2016. Dalam pengembangannya, Institut Parahikma Indonesia (IPI) Gowa mengusung semboyang "Berperadaban, Cerdas, dan Terampil" sebagai sebuah cita akademik yang menjadi menjiwai dari implementasi tri dharma perguruan tinggi yang terdiri atas pendidikan dan pengajaran, penelitian serta pengabdian pada masyarakat.

Sebagai sebuah cita akademik yang terangkum dalam sebuah semboyang, semboyang "Berperadaban, Cerdas, dan Terampil" telah menjadi sebuah "ruh" yang menggerakkan "jasad" dari seluruh civitas akademik Institut Parahikma Indonesia (IPI) Gowa. Sebagai penjabaran operasional dari semboyang "Berperadaban, Cerdas, dan Terampil" tersebut, Institut Parahikma Indonesia (IPI) Gowa telah mengajukan lima pilar pengembangan yang dalam hal ini adalah bahasa Inggris, Information, Communication, and Technology (ICT), kepemimpinan, ibadah, dan kompetensi program studi.

Perpaduan kelima pilar pengembangan tersebut merupakan suatu penjabaran dari Undang-Undang No. 20 Tahun 2003 tentang Sistem Pendidikan Nasional sebagai dasar operasional sistem pendidikan di Indonesia. Dalam ketentuan umumnya, pendidikan digambarkan sebagai usaha sadar dan terencana untuk mewujudkan suasana belajar dan proses pembelajaran agar peserta didik secara aktif mengembangkan potensi dirinya untuk memiliki kekuatan spiritual keagamaan, pengendalian diri, kepribadian, kecerdasan, akhlak mulia, serta keterampilan yang diperlukan dirinya, masyarakat, bangsa dan negara. ${ }^{1}$ Kajian ini menarik untuk dicermati mengingat beberapa penelitian yang telah dilakukan sebelumnya tentang pendidikan karakter seperti yang dilakukan oleh Muhammad Rusydi dengan judul "Pembelajaran Bahasa Arab Berbasis Pendidikan Karakter pada Character Building Program UIN Alauddin Makassar", Sarifah Suhrah yang berjudul "Strategi Guru PAI dalam Mengembangkan Pendidikan Karakter di SMA Negeri 1 Watampone" dan yang lainnya yang cenderung belum memberikan sebuah bentuk yang khas seperti yang ada di lingkungan Institu Parahikma Indonesia

\footnotetext{
${ }^{1}$ Republik Indonesia, Undang-Undang No. 20 Tahun 2003 tentang Sistem Pendidikan Nasional http://sindikker.dikti.go.id/dok/UU/UU20-2003-Sisdiknas.pdf. (24 Maret 2017)
} 
(IPI) Gowa dengan konsep ilmu hikmah sebagai sebuah kajian keagamaan dari magnum opus-nya yang dalam hal ini adalah al-Qur'an dan sunnah dengan orientasi pada sisi esoterisnya daripada sekedar berkutat pada sisi eksoterisnya.

Oleh karena itu, menarik apabila pendidikan karakter berbasis ilmu hikmah pada Institut Parahikma Indonesia (IPI) Gowa diteliti secara mendalam. Berangkat dari uraian latar belakang di atas, peneliti dapat merumuskan pokok permasalahan yaitu bagaimana pendidikan karakter berbasis ilmu hikmah pada Institut Parahikma Indonesia (IPI) Gowa. Pokok masalah tersebut kemudian dijabarkan menjadi beberapa rumusan sub-masalah yaitu 1) bagaimana implementasi pendidikan karakter berbasis ilmu hikmah pada Institut Parahikma Indonesia (IPI) Gowa dalam perspektif esoterisme agama?, 2) serta bagaimana kendala implementasi pendidikan karakter berbasis ilmu hikmah pada Institut Parahikma Indonesia (IPI) Gowa dan solusinya?. Penelitian ini tergolong jenis penelitian lapangan berorientasi data kualitatif deskriptif. Metode pengumpulan data yang dilakukan adalah wawancara (interview), observasi partisipatif (participatory observation), dokumentasi (documentation) dan penelusuran referensi (reference exploring) untuk selanjutya diolah melalui tiga tahapan secara berkesinambungan yang meliputi tahap reduksi data (data reduction), tahap penyajian data (data display), dan tahap penarikan kesimpulan/verivikasi (conclusion drawing/verivication). ${ }^{2}$ Dalam menguji keabsahan data, peneliti menggunakan triangulasi metode yaitu triangulasi waktu dan tempat. ${ }^{3}$

\section{B. Implementasi Pendidikan Karakter Berbasis Ilmu Hikmah pada Institut Parahikma Indonesia (IPI) Gowa dalam Perspektif Esoterisme Agama}

Sebagai magnum opus dari pengembangan suatu kampus, visi dari Institut Parahikma Indonesia (IPI) Gowa yang berbunyi "tercapainya pembelajaran profesional berbasis hikmah, pengembangan inner capacity, dan pembudayaan online system pada tahun 2025 (berperadaban, cerdas, dan terampil)". Visi tersebut kemudian dijabarkan

${ }^{2}$ Sugiyono, Metode Penelitian Pendidikan: Pendekatan Kuantitatif, Kualitatif, dan R\&D, (Bandung: Alfabeta, 2008), h. 337-345.

3 Ag. Bambang Setiyadi, Metode penelitian untuk Pengajaran Bahasa Asing: Pendekatan Kuantitatif dan Kualitatif, (Yogyakarta: Graha Ilmu, 2006), h. 247. 
pada beberapa misi yaitu, a) menyelenggarakan pendidikan dan dosenan berbasis hikmah yang profesional dalam mengantarkan mahasiswa meraih kecerdasan spiritual, emosional, dan intelektual, b) menyelenggarakan penelitian berbasis hikmah yang menjunjung tinggi prinsip-prinsip ilmiah dan berorientasi pada pengembangan keilmuan, c) menyelenggarakan pengabdian masyarakat berbasis hikmah dan berorientasi pada pemberdayaan umat dalam bingkai Islam rahmatan lil 'alamin, d) serta memperkuat kerja sama dengan berbagai pihak dalam dalam rangka penguatan kelembagaan.

Salah satu langkah inovatif yang dihadirkan oleh Institut Parahikma Indonesia (IPI) dalam mewujudkan visi dan misi tersebut dalam spektrum pendidikan hikmah berdasarkan semboyang berperadaban, cerdas, dan terampil adalah memperkokoh filosofi keilmuannya yang terjabarkan pada lima pilar penguatan akademik yang dalam hal ini adalah sebagai berikut: ${ }^{5}$

\section{a. Penguatan Profesionalisme Berbasis Program Studi}

Sebagai bagian dari lima pilar penguatan Institut Parahikma Indonesia (IPI), penguatan profesionalisme berbasis program studi menekankan upaya pembimbingan mahasiswa secara terstuktur dalam memperkuat profesionalisme program studi masing-masing yang diawali dengan kerangka filosofis masing-masing program studi untuk selanjutnya dibawa pada kerangka praktis yang sifatnya aplikatifresponsif terhadap kebutuhan dunia kerja. Dengan ilmu hikmah, penguatan profesionalisme berbasis program studi yang dikembangkan pada institusi ini memberikan landasan moral dalam pengembangan professional mahasiswa. Hal ini diperkuat dengan pernyataan Thomas Lickona bahwa karakter tidak berfungsi dalam ruang hampa, karakter berfungsi dalam lingkungan sosial. Sebuah lingkungan seringkali menindas kepedulian moral kita. Lingkungan sosial terkadang bahkan meciptakan keadaan yang membuat banyak atau sebagian besar orang merasa bodoh jika melakukan hal- hal bermoral. ${ }^{6}$

b. Penguatan Kemampuan Bahasa Inggris

\footnotetext{
${ }^{4}$ Muhammad Rusydi dkk. Pedoman Akademik Institut Parahikma Indonesia (IPI) Gowa, (Makassar: Parahikma Publishing, 2016), h. 3

5 Abd. Muis Said, Pengurus Yayasan Parahikma Indonesia, Wawancara, 12 Oktober 2016

6 Thomas Lickona, Pendidikan Karakter; Panduan lengkap Mendidik Siswa Menjadi Pintar dan Baik, (Bandung, Nusa Media, 2013), h. 88
} 
Selain pada kemampuan berkomunikasi dalam bahasa Inggris yang diwajibkan pada seluruh mahasiswa Institut Parahikma Indonesia (IPI), penguatan bahasa Inggris juga diarahkan pada kemampuan yang berbasis minat mahasiswa yang dalam hal ini terbagi atas English for Spesific Purpose (ESP) yang intinya mengarahkan mahasiswa untuk mendalami bahasa Inggris berdasarkan program studi masing-masing serta berbagai macam test bahasa Inggris sebagai persyaratan untuk bisa melanjutkan studi ke luar negeri seperti TOEFL/IELTS.

c. Penguatan Kemampuan ICT

Kemampuan Information, Communication, and Technology (ICT) merupakan suatu pilar penguatan berikutnya yang dikembangkan dalam lingkungan Institut Parahikma Indonesia (IPI) Gowa dimana mahasiswa dibimbing secara masif pada tahun pertama untuk dapat menguasai Microsoft Word, Excel, dan Power Point. Dalam pengembangannya, kemampuan mahasiswa dalam menggunakan Microsoft Word, Excel, dan Power Point tersebut diintegrasikan dengan pembelajaran berbasis online system yang dalam hal ini mengadopsi Google Classroom sehingga mahasiswa memiliki kemampuan untuk lebih mandiri meningkatkan kemampuan profesionalisme mereka baik dalam bentuk hard skill yang sesuai dengan latar belakang keilmuannya ataupun berupa soft skill yang berbeda dengan dengan latar belakang keilmuannya sambil berselancar di dunia maya.

d. Penguatan Jiwa Kepemimpinan

Dalam kerangka filosofisnya, penguatan jiwa kepemimpinan mahasiswa, Institut Parahikma Indonesia (IPI) Gowa mengadopsi nilainilai hikmah yang terkandung dari ajaran para wali tentang hakikat penciptaan manusia sebagai khalifatullah di muka bumi yang membawa misi kemaslahatan bagi seluruh alam dalam spektrum kehidupan modern yang dalam kerangka filsafatnya merupakan merupakan penjabaran dari perpaduan antara filsafat perennialisme dan filsafat progressivisme. Dalam kerangka praktisnya, penguatan jiwa kepemimpinan mahasisiwa Institut Parahikma Indonesia (IPI) Gowa ditanamkan sejak awal dimana mereka yang memiliki kemampuan lebih atas yang lainnya khususnya dalam bidang bahasa Inggris dan ICT diberikan kesempatan untuk membimbing rekan seangkatannya pada bidang keahlian yang dikuasainya. Dalam konteks ini, Institut Parahikma Indonesia (IPI) mengadopsi salah satu kesuksesan yang dipraktikkan di Pondok Pesantren Gontor yang dalam hal ini adalah santri/mahasantri yang 
berada pada tingkatan atas mengajar mereka yang berada tingkatan di bawahnya. Penguatan jiwa kepemimpinan tersebut tercermin dari motto Institut Parahikma Indonesia (IPI) Gowa yang dalam hal ini adalah "berperadaban (daya kalbu), cerdas (daya pikir), dan terampil (daya hidup)"

Menyikapi penguatan jiwa kepemimpinan sebagai bagian dari pendidikan karakter berbasis tersebut, Zubaedi menyatakan bahwa pendidikan karakter merupakan upaya penanaman kecerdasan dalam berfikir, penghayatan dalam bentuk sikap, dan pengamalan dalam bentuk perilaku yang sesuai dengan nilai-nilai luhur yang menjadi jati dirinya, diwujudkan dalam interaksi dengan Tuhannya, diri sendiri, masyarakat dan lingkungannya. ${ }^{7}$

e. Penguatan Ibadah

Posisi ibadah sebagai suatu ritual yang berkaitan erat dengan misi penciptaan manusia (QS.Adz-Dzariyat/51:56) diaplikasikan dalam lingkungan Institut Parahikma Indonesia (IPI) berupa penguatan ibadah yang dalam hal ini ditekankan pada pemahaman makna literal dan nonliteral dari berbagai bacaan yang dibaca saat beribadah pada Allah Swt., khususnya shalat yang menjadi pilar agama Islam. Dalam kerangka penguatan ibadah ini, Institut Parahikma Indonesia (IPI) Gowa berkeyakinan bahwa pemahaman makna literal dan non-literal dari berbagai bacaan yang dibaca saat beribadah pada Allah Swt., khususnya shalat yang menjadi pilar agama Islam akan memunculkan shalat yang khusyu' yang pada gilirannya akan memunculkan sisi aksiologis shalat yaitu shalat yang mampu mencegah dari perbuatan keji dan mungkar.

Dari kelima pilar pengembangan tersebut, konsep pendidikan karakter tergambar jelas dalam pendidikan hikmah yang dibangun atas semboyang berperadaban, cerdas, dan terampil. Menyikapi hal tersebut, Yamin sebagai salah seorang pendakwah, istilah yang digunakan bagi penceramah dari Jam'iyyatul Islamiyah (JMI), menyatakan bahwa pendidikan hikmah merupakan optimalisasi segala potensi ruh yang ada dalam diri manusia yang telah ditiupkan oleh Allah Swt. sebagaimana dijelaskan dalam QS. As-Sajadah/32:9. Dalam proses tersebut, relasi jazad dan ruh yang ditiupkan adalah mitra yang memiliki karakter yang berbeda. Fisik dengan sifatnya nasutnya cenderung pada dunia yang pragmatis sementara ruh dengan sifat lahutnya cenderung pada ketaatan

\footnotetext{
${ }^{7}$ Zubaedi, Desain Pendidikan Karakter: Konsepsi dan Aplikasinya dalam Lembaga Pendidikan, (Jakarta: Kencana, 2011), h. 17.
} 
sebagai seorang hamba. Fenomena tersebut telah digambarkan oleh Najib Sulhan yang menyatakan bahwa manusia pada dasarnya memiliki dua potensi karakter yaitu karakter yang baik serta karakter yang buruk yang tentu saja saling berlawanan satu sama lain.

Yamin melanjutkan bahwa potensi yang telah ditanamkan tersebut harus dimaksimalkan demi menunjang eksistensi manusia di muka bumi sebagai seorang hamba. ${ }^{9}$ Dalam upaya mewujudkan upaya tersebut, semua civitas akademika Institut Parahikma Indonesia (IPI) Gowa diwajibkan mengikuti pengajian wiridan tiap malam kamis dengan menghadirkan 3 orang pendakwah lokal yang dalam hal ini adalah Dr. Tasmin Tangngareng, Dr. Tasbih Hanafiah, dan Dr. Yamin dengan memberikan uraian materi yang mengacu pada konsep pendidikan karakter berbasis ilmu hikmah pada Institut Parahikma Indonesia (IPI) Gowa. Di samping beberapa pendakwah lokal di atas, Prof. Dr. H. Azhar Arsyad, M.A. sebagai Sekretaris Jenderal Jam'iyyatul Islamiyah (JMI) juga biasa bertindak sebagai pendakwah apabila kemudian ketiga pendakwah yang telah disebutkan namanya di atas berhalangan hadir.

Dalam penelusuran peneliti terhadap materi-materi yang disampaikan dalam pengajian wiridan tergambar bagaimana fungsi ruh dikembangkan sedemikian rupa dalam membentuk karakter peserta didik dalam lingkungan Institut Parahikma Indonesia (IPI) Gowa. Hal yang unik kemudian diperhatikan dalam kaitannya dengan optimalisasi potensi ruh dengan merujuk pada QS. al-Isra'/17: 85:

Menyikapi optimalisasi potensi ruh pada ayat di atas, apa yang dipahami oleh kebanyakan orang bahwa ruh yang menjadi urusan Tuhan membuat ruh menjadi suatu hal yang tidak tersentuh oleh pengetahuan manusia justri dipahami sebagai sarana untuk mengenal Tuhan sehingga pada akhirnya akan bermuara pada meningkatnya potensi manusia. Menyikapi hal tersebut, Suhatnam yang merupakan salah seorang dosen dalam lingkungan Institut Parahikma Indonesia (IPI) Gowa menyatakan bahwa ruh yang dipahami dalam lingkungan Institut Parahikma Indonesia (IPI) Gowa sebagai urusan Tuhan harus dipahami sebagai sarana dalam mengenal Tuhan. Logika sederhananya adalah apabila kita ingin mengenal seorang anak maka mengenal orang tua yang

${ }^{8}$ Najib Sulhan, Pendidikan Berbasis Karakter: Sinergi antara Sekolah dan Rumah dalam Membentuk Karakter Anak, (Surabaya: PT.JePe Press Media Utama, 2010), h. 1 ${ }^{9}$ Yamin, Pendakwah Jam'iyyatul Islamiyah (JMI) dalam lingkungan Institut Parahikma Indonesia (IPI) Gowa, wawancara, 12 Oktober 2016. 
mengurusnya sejak kecil merupakan salah satu cara dalam mengenal anak tersebut. Mengenal ruh yang telah ditiupkan Tuhan dalam diri manusia merupakan salah satu kunci dalam membentuk karakter mahasiswa secara khusus dan seluruh civitas akademika Institut Parahikma Indonesia (IPI) Gowa secara umum. ${ }^{10}$

Senada dengan uraian di atas, Waryani Fajar Riyanto dengan mendokumentasikan bahan-bahan pengajian yang telah disampaikan oleh Buya Aswin Rose selaku Ketua Dewan Pembina Jam'iyyatul Islamiyah (JMI) untuk selanjutnya menjadi bahan kajian pokok dalam lingkungan Institut Parahikma Indonesia (IPI) Gowa mengemukakan bahwa Allah Swt. menyempurnakan kejadian manusia dengan meniupkan ruh. Kemudian manusia bersifat lain, yang ditimbulkan oleh bisikan setan, sebangsa jin dan manusia; dan sifat itu dapat kita ketahui setelah adanya ruh yang dianugerahkan Allah Swt. bersamaan dengan nikmat atau zat atau rasa. Dengan nikmat atau zat atau rasa itu, dapat kita merasakan adanya sifat setan, sifat manusia, dan adanya sifat jin pada tiap-tiap diri manusia. Sifat setan itu adalah pembohong, penghasut, dan pemfitnah. Sifat manusia dapat dirasakan, apabila dia menderita dia berputus asa, apabila dia kaya dia kikir. Sifat jin, adalah suatu perbuatan yang di luar kesadaran normal yang tidak terkendali. Ternyata, kepintaran manusia setinggi apapun, tidak mampu membedah ontologi setan, sifat manusia, dan jin. Sebaliknya, ruh yang ditiupkan ke dalam manusia, untuk menyempurnakan kejadian manusia, berarti manusia itu tidak sempurna, bersifat siddiq, amānah, tablig, dan fatānah. Manusia pada umumnya bersifat hawa (anāsir angin), nafsu (anāsir air), dunia (anāsir tanah), dan setan (anāsir api), yang terhimpun dalam nafsu lawwāmmah (anāsir angin + anāsir tanah) dan nafsu ammārah (anāsir air + anasir api). Perbedaan sifat manusia dan sifat ruh inilah, yang dapat kita rasakan bermula dari sebuah keragu-raguan, yang kemudian memberikan gambaran sebagai sebuah sifat pembawaan atau karakter yang berbeda satu sama lain, yang dibentuk oleh pendidikan dan lingkungan dimana manusia dibesarkan. ${ }^{11}$

Proses pembagian potensi ruh dalam ilustrasi di atas menunjukkan bahwa proses pengasahan karakter baik dari ruh yang

\footnotetext{
${ }^{10}$ Suhatnam, Dosen Institut Parahikma Indonesia (IPI) Gowa, wawancara, 16 Oktober 2016.

${ }^{11}$ Waryani Fajar Riyanto, Mengembalikan Hakikat Yang Hilang: Baitullah, (Jakarta: DPP Jam'iyyatul Islamiyah, 2015), h.165
} 
dalam hal ini adalah șiddiq, amānah, tablig, dan fatānah harus dilakukan dengan membentuk lingkungan yang mendukung proes tersebut. Dalam pengamatan peneliti dalam lingkungan Institut Parahikma Indonesia (IPI) Gowa, terlihat bahwa pihak lembaga senantiasa berupaya menciptakan lingkungan pendidikan yang mendukung pengembangan pendidikan karakter berbasis hikmah yang diusung oleh lembaga. Hal itu tergambar pada kehidupan mahasiswa yang tinggal di asrama kampus 2 yang berlokasi di kampus 2 Jl. Tamangapa Raya No.168 Antang yang sangat menekankan penggunaan bahasa Inggris sebagai bahasa komunikasi sehari-hari. Rubiana Murtasam yang merupakan salah seorang mahasiswi yang tinggal dalam asrama mengemukakan bahwa bahasa yang digunakan dalam komunikasi sehari-hari di asrama adalah bahasa Inggris. Kebijakan ini sangat membantu karena kemampuan berbahasa Inggris merupakan suatu kemampuan yang sangat tergantung dengan pembiasaan. ${ }^{12}$ Dalam pengamatan peneliti, pembelajaran bahasa asing, khususnya bahasa Inggris, dalam lingkungan Institut Parahikma Indonesia (IPI) Gowa selalu disinergikan dengan epistemology keilmuan dari pembelajaran bahasa asing yang dikembangkan oleh Azhar Arsyad yang dalam hal ini adalah diawali dengan hafalan perbendaharaan kata dengan merujuk pada obyek empiris di lapangan sebagai manifestasi dari empirisme, lalu dilanjutkan dengan praktik drill dengan merujuk pada analisis logis sebagai manifestasi dari rasionalisme, lalu dilanjutkan dengan aktivasi ruh dalam mencari pemberian intuitif melalui pemberian motivasi sebagai bagian dari transformasi sisi esoterisme agama dalam pendidikan karakter.

Dalam wawancara peneliti dengan Azhar Arsyad, peneliti mendapatkan gambaran bahwa pemberian motivasi merupakan cara yang paling efektif dalam membangkitkan karakter peserta didik khususnya yang berlevel mahasiswa. Oleh karena itu, mahasiswa dalam lingkungan Institut Parahikma Indonesia (IPI) Gowa diwajibkan untuk mengikuti Program Pencerahan Imani dan Keterampilan Hidup (PIKIH) dari hari Senin sampai Jum'at setiap minggunya dengan menerima salah satu

\footnotetext{
${ }^{12}$ Rubiana Murtasam, Mahasiswi Institut Parahikma Indonesia (IPI) Gowa, wawancara, 15 Oktober 2016
} 
materi pemberian motivasi melalui buku Step by Step, al-Qira'ah alAshriyyah, Balagah al-Hukama, dan yang lainnya.

Dalam pengamatan peneliti, mahasiswa Institut Parahikma Indonesia (IPI) Gowa selalu menjadikan lima pilar pengembangan yang adalah hal ini adalah profesionalisme program studi, bahasa Inggris, Information, Communication and Technology (ICT), kepemimpinan, dan ibadah menjadi kerangka dasar proses perkuliahan dalam membentuk karakter mahasiswa berbasis ilmu hikmah. Hal ini terlihat dalam proses perkuliahan yang peneliti amati dengan mata kuliah pancasila dan kewarganegaraan. Dalam penerapannya, dosen yang mengajarkan mata kuliah pancasila dan kewarganegaraan pada pertemuan kedua dengan topik pembahasan yaitu pancasila sebagai pandangan hidup. Dosen yang bersangkutan membukaa kelas dengan menggunakan bahasa Inggris dengan mengatakan "Dear ladies and gentlemen! We would like to learn a topic namely pancasila as the way of life" lalu menginstruksikan mahasiswa mencari topik yang dimaksud dengan mengatakan "To find out the topic, would you like to search on your computer". Setelah mahasiswa mendapatkan artikel atau makalah tentang pancasila sebagai pandangan hidup, dosen kemudian mengarahkan mereka untuk mengungkapkan apa yang mereka pahami berkaitan dengan topik yang dimaksud dengan mempergunakan bahasa Inggris lalu kemudian didiskusikan dengan bahasa Inggris pula. Dalam perkembangannya, topik tersebut dibawa pada analisis kasus untuk mengembangkan jiwa kepemimpinan mahasiswa untuk memecahkannya. Adapun dalam kaitannya dengan ibadah dan profesionalisme program studi, lebih difokuskan pada mata kuliah tertentu yang kemudian menjadi common ground fakultas dan program studi.

Pendidikan karakter berbasis ilmu hikmah pada Institut Parahikma Indonesia (IPI) Gowa tersebut merupakan bentuk kajian esoterisme agama dalam pendidikan karakter yang khas tapi memiliki relevansi dengan berbagai konsep pendidikan karakter seperti yang dilakukan oleh beberapa tokoh pendidikan seperti al-Ghazali yang memperkenalkan konsep epistemologi keraguan sufistiknya menekankan perlunya ilmu pengetahuan diawali dengan melapangkan hati dari

13 Azhar Arsyad, Rektor Institut Parahikma Indonesia (IPI) Gowa, wawancara, 15 Oktober 2016 
berbagai sifat-sifat tercela sampai datangnya cahaya dari Allah swt., ${ }^{14}$ Mansyur Ramli yang memperkenalkan konsep pendidikan karakter bangsa dengan empat pilarnya yaitu olah pikir, olah hati, olah rasa, dan olah raga, ${ }^{15}$ Azhar Arsyad yang memperkenalkan konsep inner capacity dengan tiga pilar yaitu daya hidup, daya qalbu, dan daya pikir, ${ }^{16}$ Qadir Gassing dengan konsep character building dengan tiga pilar yaitu pencerahan, pencerdasan, dan prestasi, $^{17}$ serta berbagai konsep pendidikan karakter lainnya.

\section{Kendala Implementasi Pendidikan Karakter Berbasis Ilmu Hikmah pada Institut Parahikma Indonesia (IPI) Gowa dan Solusinya}

Dalam upaya implementasi pendidikan karakter berbasis ilmu pada Institut Parahikma Indonesia (IPI) Gowa, pihak kampus yang menggunakan pendakwah, dosen, dan staf sebagai pihak-pihak yang terlibat langsung dalam kegiatan tersebut mengalami beberapa kendalakendala yang merupakan hal yang wajar dalam setiap kegiatan akademik di manapun pelaksanaannya.

Kendala yang dihadapi adalah belum membudayanya pendidikan karakter berbasis ilmu di Indonesia menjadi tantangan tersendiri bagi upaya pengembangannya. Hal ini menyebabkan baik pendidik maupun peserta didik belum terbiasa dengan model pendidikan karakter. Dibutuhkan komitmen yang kuat untuk bisa merancang dan melaksanakan program ini dengan efektif. Selain itu, sumber-sumber informasi yang tersedia lebih banyak mengacu model di negara lain yang budaya dan kebutuhannya relatif berbeda dengan Indonesia. Menyikapi hal tersebut, Abdullah Muhammad yang merupakan dosen dalam lingkungan Institut Parahikma Indonesia (IPI) Gowa menggambarkan bahwa kajian-kajian wiridan sebagai bagian pendidikan karakter berbasis ilmu hikmah pada Institut Parahikma Indonesia (IPI)

\footnotetext{
14 Al-Ghazali, "al-Munqidz min al-Dhalal" dalam Majmu'ah Rasail al-Imam alGhazali, (Beirut: Dar al-Fikr, 2006), h. 539-540

${ }^{15}$ Mansyur Ramli, Pembangunan Berbasis Pendidikan Karakter Bangsa, Power Point: Disampaikan pada Musyawarah Daerah Majaelis Ulama Indonesia (MUI) Propinsi Sulawesi Selatan (Sudiang, 02 April 2011)

${ }^{16}$ Azhar Arsyad, Membangun Universitas Menuju Peradaban Islam Modern, (Makassar: Alauddin Press, 2009), h. 21

17 Slogan ini menjadi ikon pengembangan pendidikan karakter melaui Character Buiding Program pada masa kepemimpinan Prof. Dr. H.A. Qadir Gassing, HT., MS., sebagai Rektor UIN Alauddin Makassar Periode 2010-2014.
} 
Gowa merupakan suatuhal yang baru baginya karena menyentuh sisi esoteris suatu obyek kajian.

Apa yang digambarkan oleh Abdullah Muhammad tersebut bisa dipahami mengingat pendidikan karakter yang selama ini dikembangkan cenderung berkutat pada wilayah eksoteris cenderung hanya berkutat pada wilayah pragmatis suatu obyek kajian dari sisi kulit luarnya. Konsekuensinya, hasil pendidikan karakter tersebut cenderung mengukur keberhasilannya dari sisi ukuran intelektual, emosional, dan spiritual sebagai bagian penjabaran dari kompetensi yang sifatnya pragmatisantroposentris.

Dalam mengatasi kendala tersebut, solusi yang dilakukan oleh Institut Parahikma Indonesia (IPI) Gowa adalah mengintensifkan pengajian wiridan setiap malam kamis dengan mewajibkan seluruh civitas akademika untuk mengikuti pengajian wiridan tersebut. Hal ini tentunya merupakan bentuk sosialisasi pada seluruh civitas akademika tentang pendidikan karakter berbasis ilmu hikmah tersebut.

Sementara itu, kendala yang dihadapi oleh dosen adalah masih minimnya pelatihan khusus bagi mereka tentang implementasi pendidikan karakter berbasis ilmu hikmah. Asfiah Syam yang merupakan dosen bahasa Arab mengatakan bahwa dia mengetahui perlunya implementasi nilai-nilai karakter berbasis ilmu hikmah yang meliputi lima pilar pengembangan yang dalam hal ini adalah profesionalisme program studi, bahasa Inggris, Information, Communication and Technology (ICT), kepemimpinan, dan ibadah hanya saja manakal dia diminta untuk mengaitkannya dengan ilmu hikmah sebagai magnum opus-nya, dia mengaku mengalami beberapa kendala khususnya tentang konsep dasarnya.

Dalam pengamatan peneliti, ada juga dosen bahasa Arab yang mengabaikan implementasi nilai-nilai karakter berbasis ilmu hikmah pada proses pembelajaran karena lebih sibuk pada upaya untuk melatih aspek kompetensi dari mata kuliah yang diajarkan. Apakah karena mereka menganggap bahwa kompetensi mata kuliah lebih penting dibandingkan dengan implementasi nilai-nilai karakter berbasis ilmu hikmah seperti nilai karakter dalam hubungannya dengan Tuhan, nilai

${ }^{18}$ Abdullah Muhammad, Dosen Institut Parahikma Indonesia (IPI) Gowa, wawancara, 15 Oktober 2016

${ }^{19}$ Asfiah Syam, Dosen Dosen Institut Parahikma Indonesia (IPI) Gowa, wawancara, 15 Oktober 2016 
karakter dalam hubungannya dengan diri sendiri, nilai karakter dalam hubungannya dengan sesama, nilai karakter dalam hubungannya dengan lingkungan, dan nilai karakter dalam hubungannya dengan kebangsaan pada pembelajaran bahasa Arab menjadi suatu pertanyaan tersendiri. Peneliti melihat poin yang kedua yaitu minimnya pemahaman mereka terhadap teknis implementasi nilai-nilai karakter berbasis ilmu hikmah menjadi sebuah asumsi yang bisa merefleksikan fenomena tersebut.

Dalam mengatasi kendala tersebut, pihak pimpinan di bawah kontrol yayasan Parahikma Indonesia telah melakukan langkah-langkah antisipatif yaitu dengan memberikan penyampaian lisan kepada para dosen tentang perlunya implementasi nilai-nilai karakter berbasis ilmu hikmah pada kegiatan pembelajaran. Adapun hal yang harus dilakukan ke depannya adalah melakukan kegiatan workshop implementasi pembelajaran pendidikan karakter berbasis ilmu hikmah bagi seluruh dosen termasuk dengan mewajibkan dosen-dosen mengikuti wiridan bersama dengan mahasiswa tiap malam kamis.

Sementara itu, kendala yang dihadapi oleh mahasiswa adalah padatnya kegiatan perkuliahan baik yang regular ataupun non-regular yang dalam hal ini adalag Program Pencerahan Imani dan Keterampilan Hidup (PIKIH) sehingga mengakibatkan kelelahan bagi mahasiswa sehingga mereka kurang fokus dalam menyerap pendidikan karakter berbasis ilmu hikmah tersebut. Dalam mengatasi kendala tersebut, solusi yang dilakukan adalah melakukan format pembelajaran yang aktif, inovatif, kreatif, efektif dan menyenangkan yang dalam hal ini adalah dengan memperbanyak kegiatan komunikatif-interaktif.

Berdasarkan paparan di atas, dapat dipahami bahwa kendala yang dihadapi dalam implementasi pendidikan karakter berbasis ilmu hikmah dalam lingkungan Institut Parahikma Indonesia (IPI) Gowa mencakup tiga aspek yang dalam hal ini ilmu hikmah yang belum memasyarakat, pemahaman dosen yang belum maksimal, serta keterbatasan mahasiswa dalam memahami akibat beberapa faktor. Solusinya kemudian adalah mengintensifkan transformasi ilmu hikmah pada lima pilar pengembangan dalam semboyang berperadaban, cerdas, dan terampil.

\section{Kesimpulan}

Implementasi pendidikan karakter berbasis ilmu hikmah pada Institut Parahikma Indonesia (IPI) Gowa selalu dikaitkan dengan lima pilar pengembangan yang dalam hal ini adalah profesionalisme program 
studi, bahasa Inggris, Information, Communication and Technology (ICT), kepemimpinan, dan ibadah yang pada awalnya telah didahului dengan penguatan pemahaman mahasiswa tentang hakikat penciptaan dirinya di muka bumi sebagai bagian dari esoterisme agama.

Kendala yang dihadapi dalam implementasi pendidikan karakter berbasis ilmu hikmah dalam lingkungan Institut Parahikma Indonesia (IPI) Gowa mencakup tiga aspek yang dalam hal ini ilmu hikmah yang belum memasyarakat, pemahaman dosen yang belum maksimal, serta keterbatasan mahasiswa dalam memahami akibat beberapa faktor. Solusinya kemudian adalah mengintensifkan transformasi ilmu hikma dalam lima pilar pengembangan dalam semboyang berperadaban, cerdas, dan terampil.

Penelitian ini memberikan implikasi bahwa pendidikan karakter merupakan suatu inovasi pendidikan yang membutuhkan suau paradigma yang khas. Konsep pendidikan karakter berbasis pendidikan hikmah seperti apa yang ada dalam lingkungan Institut Parahikma Indonesia (IPI) Gowa telah menjadi suatu model pendidikan karakter yang khas karena didasari oleh semboyang berperadaban, cerdas, dan terampil pada tataran idenya sementara tataran praktisnya didasari oleh lima pilar pengembangan yang terdiri atas profesionalisme program studi, bahasa Inggris, Information, Communication, and Technology (ICT), kepemimpinan, dan ibadah.

\section{Daftar Pustaka}

Al-Ghazali, "al-Munqidz min al-Dhalal" dalam Majmu'ah Rasail alImam al-Ghazali, Beirut: Dar al-Fikr, 2006.

Republik Indonesia, Undang-Undang No. 20 Tahun 2003 tentang Sistem Pendidikan Nasional http://sindikker.dikti.go.id/dok/UU/UU202003-Sisdiknas.pdf. (24 Maret 2017)

Sulhan, Najib, Pendidikan Berbasis Karakter: Sinergi antara Sekolah dan Rumah dalam Membentuk Karakter Anak, Surabaya: PT.JePe Press Media Utama, 2010.

Ramli, Mansyur, Pembangunan Berbasis Pendidikan Karakter Bangsa, Power Point: Disampaikan pada Musyawarah Daerah Majaelis Ulama Indonesia (MUI) Propinsi Sulawesi Selatan (Sudiang, 02 April 2011) 
Arsyad, Azhar, Membangun Universitas Menuju Peradaban Islam Modern, Makassar: Alauddin Press, 2009.

Lickona, Thomas, Pendidikan Karakter; Panduan lengkap Mendidik Siswa Menjadi Pintar dan Baik, Bandung, Nusa Media, 2013.

Zubaedi, Desain Pendidikan Karakter: Konsepsi dan Aplikasinya dalam Lembaga Pendidikan, Jakarta: Kencana, 2011.

Azhar Arsyad, Dari Mana, Mau Kemana, Di Mana Tempat Kembali, Disampaikan pada Koordinasi Dosen Institut Parahikma Indonesia Menyambut Perkuliahan Semester Ganjil 2016-2017, Paccinongan 13 September 2016.

Sugiyono, Metode Penelitian Pendidikan: Pendekatan Kuantitatif, Kualitatif, dan R\&D, Bandung: Alfabeta, 2008.

Setiyadi, Ag. Bambang, Metode penelitian untuk Pengajaran Bahasa Asing: Pendekatan Kuantitatif dan Kualitatif, Yogyakarta: Graha Ilmu, 2006.

Rusydi, Muhammad dkk. Pedoman Akademik Institut Parahikma Indonesia (IPI) Gowa, (Makassar: Parahikma Publishing, 2016.

Riyanto, Waryani Fajar, Mengembalikan Hakikat Yang Hilang:

Baitullah, Jakarta: DPP Jam'iyyatul Islamiyah, 2015. 